УДК 658.14 (477.8): 339.92

\author{
Шубалий О.М., д.е.н., професор \\ Завідувач кафедри економіки \\ Shubalyi O., Doctor of Economics, Professor \\ https://orcid.org/0000-0002-9131-1896 \\ Гриник I.C., аспірант кафедри економіки \\ Hrynyk I. \\ Postgraduate student of the Department of Economics
}

\title{
ТЕНДЕНЦІЇ ФІНАНСОВОГО ЗАБЕЗПЕЧЕННЯ ІНВЕСТИЦЙНОӦ ДІЯЛЬНОСТІ У ПІВНІЧНО-ЗАХІДНОМУ РЕГІОНІ УКРАЇНИ
}

\author{
Луцький національний технічний університет
}

\begin{abstract}
У статті вивчено тенденції фінансового забезпечення інвестиційної діяльності у ПівнічноЗахідному регіоні України, до якого відносять Волинську та Рівненську адміністративні області, для виявлення проблемних сфер та виділення перспективних напрямів активізації інвестиційної діяльності. Враховуючи низький рівень економічного розвитку цих областей, забезпечення їх зростання вбачається в необхідності залучення додаткових інвестицій, особливо капітального характеру. Для проведення аналізу фінансового забезпечення інвестиційної діяльності основну увагу доцільно зосередити на вивченні показника капітальних інвестицій, адже саме такі вкладення формують базу матеріальних і нематеріальних активів тривалого користування, які становитимуть основу для подальшого економічного розвитку Північно-Західного регіону. За реальними оцінками обсяг капітального інвестування залежить від економічної ситуації в країні та $\epsilon$ нестабільним. Протягом аналізованого періоду основним джерелом фінансування капітальних інвестицій були власні кошти підприємств і організацій. У періоди економічної нестабільності прогнозовано підприємства і організації збільшували частку капітальних інвестицій 3 власних джерел. Частка фінансування капітальних інвестицій $з$ держаного бюджету була найменшою. Аналіз динаміки капітальних інвестицій в охорону навколишнього природного середовища показав, що основними напрямками інвестування стали очищення зворотних вод та поводження з відходами. Зроблено висновок, що в наступних періодах особливе значення для Північно-Західного регіону має створення сприятливих умов для збільшення капітальних інвестицій як в матеріальні, так і нематеріальні активи, адже вони забезпечать оновлення основного капіталу на інноваційній основі, що дозволить збільшити виробництво конкурентоспроможної на внутрішньому та зовнішньому ринках збуту продукції на основі залучення потужного природно-ресурсного потенціалу даного марко регіону, що в кінцевому підсумку сприятиме підвищення рівня його соціально-економічного розвитку.
\end{abstract}

Ключові слова: фінансове забезпечення, інвестиційна діяльність, капітальні інвестиції, іноземні інвестииії, Північно-Західний регіон.

\section{TENDENCIES OF FINANCIAL SUPPORT OF INVESTMENT ACTIVITY IN THE NORTHWESTERN REGION OF UKRAINE}

\author{
Lutsk National Technical University
}

The article examines the trends of financial support for investment activities in the North-Western region of Ukraine, which includes Volyn and Rivne administrative regions, to identify problem areas and identify promising areas for investment intensification. Given the low level of economic development of these areas, ensuring their growth is seen in the need to attract additional investment, especially capital. To analyze the financial support of investment activities, it is advisable to focus on the study of capital investment, because such investments form the basis of tangible and intangible fixed assets, which will form the basis for further economic development of the North-West region. According to real estimates, the amount of capital investment depends on the economic situation in the country and is unstable. During the analyzed period, the main source of financing capital investments were the own funds of enterprises and organizations. During periods of economic instability, enterprises and organizations are projected to increase the share of capital investment from their own sources. The share of financing capital investments from the state budget was the smallest. The analysis of the dynamics of capital investments in environmental protection showed that the main areas of investment were return water treatment and waste management. It is concluded that in the following periods it is especially important for the 
North-West region to create favorable conditions for increasing capital investment in both tangible and intangible assets, as they will provide renewal of fixed capital on an innovative basis, which will increase competitive production domestically and externally. markets for products based on the involvement of a powerful natural resource potential of the brand in the region, which will ultimately help increase the level of its socio-economic development.

Key words: financial provision, investment activity, capital investments, foreign investments, North-West region.

Постановка проблеми у загальному вигляді та ії зв'язок 3 важливими науковими чи практичними завданнями. Забезпечення сталого розвитку регіонів країни потребує належного фінансування важливих напрямів їх економічної діяльності, які в найближчій перспективі дозволять отримати позитивні результати. До перспективних економічних районів, або макро регіонів України, які не набули високого рівня розвитку, але мають вигідне географічне розташування й значний природноресурсний потенціал відносять Північно-Західний регіон, до якого відносять Волинську та Рівненську адміністративні області. Враховуючи низький рівень економічного розвитку цих областей, забезпечення їх зростання вбачається в необхідності залучення додаткових інвестицій, особливо капітального характеру. Тому важливе значення має вивчення теперішнього стану фінансового забезпечення інвестиційної діяльності у даному макро регіоні, що дозволить виявити можливі резерви та обгрунтувати напрями активізації інвестиційної діяльності

Аналіз останніх досліджень, у яких започатковано вирішення проблеми. Проблемні питання фінансового забезпечення інвестиційної діяльності на регіональному рівні досліджувалися багатьма вченими відомих наукових установ, зокрема ДУ «Інститут економіки природокористування та сталого розвитку НАН України» [1], ДННУ «Академія фінансового управління» [2], а також рядом інших дослідників [3-8].

Статистична інформація та окремі аналітичні огляди про зміну показників капітальних інвестицій за регіонами України за тривалий часовий проміжок у вільному доступі представлена як на офіційному веб-сайті Державної служби статистики України [11], так і на окремих офіційних веб-сайтах Головного управління статистики у Волинській області [9] та Головного управління статистики у Рівненській області [10]. Таким чином, сформоване певне теоретичне та економіко-статистичне підгрунтя для подальшого проведення аналізу тенденцій зміни показників, які характеризують фінансове забезпечення інвестиційної діяльності у Північно-Західному регіоні України.

Цілі статті. Мета дослідження полягає у вивченні тенденцій фінансового забезпечення інвестиційної діяльності у Північно-Західному регіоні України для виявлення проблемних сфер та виділення перспективних напрямів активізації інвестиційної діяльності.

Виклад основного матеріалу дослідження 3 повним обгрунтуванням отриманих наукових результатів. Як зазначалося, до складу Північно-Західного регіону України відносяться Волинська та Рівненська області, які є достатньо подібними як за природно-кліматичними умовами, так і за рівнем економічного розвитку, що дозволяє розглядати їх як єдиний економічний район, або макро регіон, який в перспективі в процесі реалізації адміністративної реформи може бути виділений в нову велику адміністративну область.

Разом з тим, в розмірах та тенденціях зміни окремих економічних показників, а також за рівнем розвитку окремих галузей господарського комплексу дані області мають й ряд відмінностей, які також потрібно врахувати в процесі аналізу. Тому виникатиме необхідність порівняльного аналізу ряду показників як окремо по Волинській та Рівненській областях, так і по Північно-Західному регіоні загалом. 
Для проведення аналізу фінансового забезпечення інвестиційної діяльності основну увагу доцільно зосередити на вивченні показника капітальних інвестицій, адже саме такі вкладення формують базу матеріальних і нематеріальних активів тривалого користування, які становитимуть основу для подальшого економічного розвитку Північно-Західного регіону. Разом з тим, важливе значення при вивченні тенденцій зміни вартісних показників за тривалий часовий період має також врахування фактору часу, що передбачає коригування номінальних показників кожного року та індекс інфляції наростаючим підсумком з початкового року аналізу. Це дозволить перевести номінальні показники в реальні в умовних цінах базового початкового року проведення аналізу й забезпечить порівнюваність вартісних даних, усунувши вплив інфляційного чинника.

На початковому етапі аналізу доцільно порівняти зміну номінальних і реальних показників капітальних інвестицій у Волинській та Рівненській областях за 20102019 рр.(рис. 1).

Як видно з рисунку, сума номінальних капітальних інвестицій протягом усього аналізованого періоду щороку переважно збільшувалася як у Волинській, так і у Рівненській областях. При цьому найбільше зростання спостерігалося протягом періоду 2015-2019 рр. Тільки у 2019 році по Рівненській області допущено зниження суми капітальний інвестицій до попереднього року на 498,8 млн грн, або 6,9\%. Загалом також спостерігається закономірність, що, починаючи з 2011 року, сума капітальних інвестицій у Волинській області постійно переважала відповідний показник у Рівненській області. При цьому, найбільше відхилення спостерігалося саме в кінці аналізованого періоду - у 2019 році, що свідчить про наявність певних проблем з активізацією інвестиційної діяльності у даному регіоні.

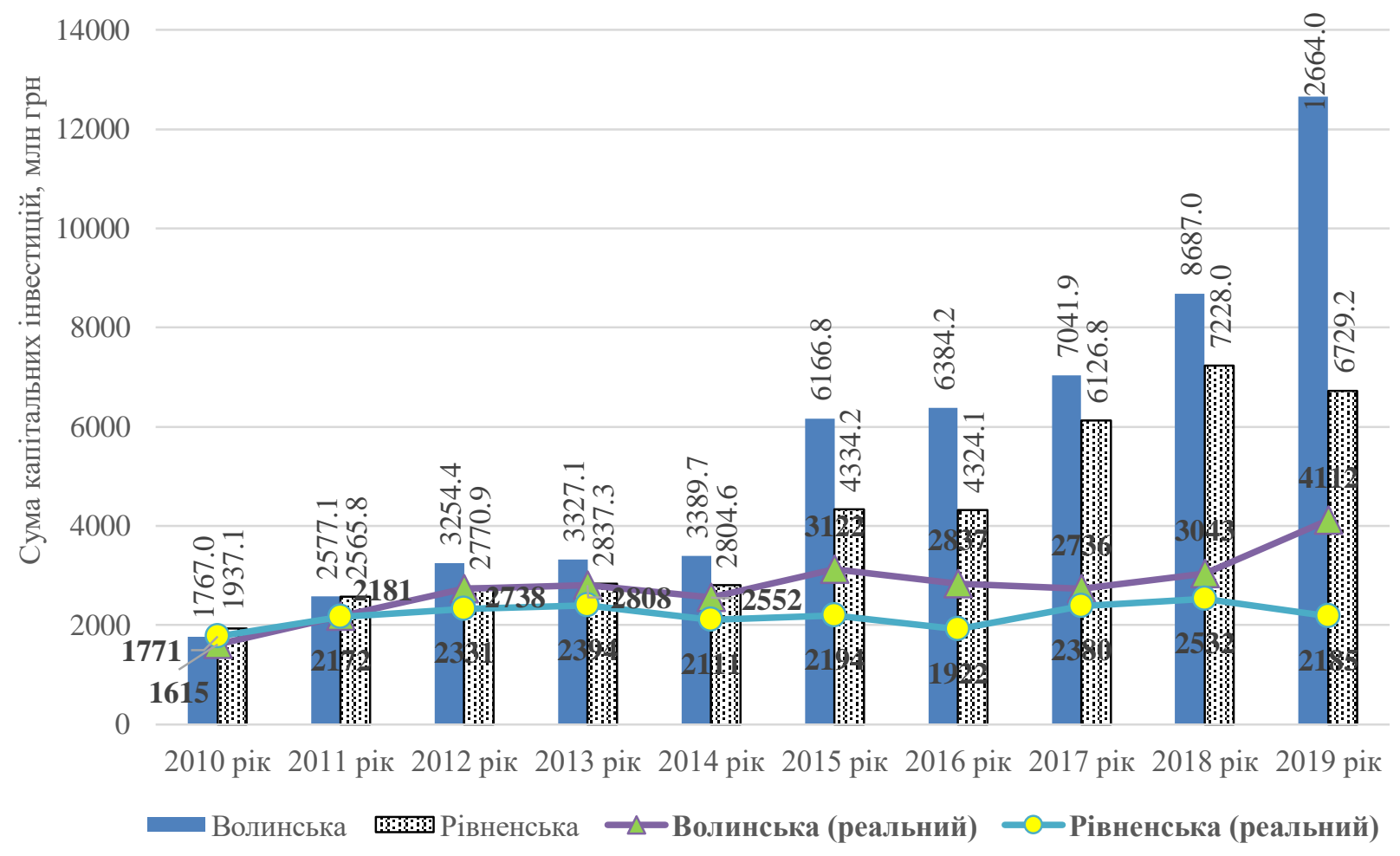

Рис. 1. Порівняння динаміки номінальних та реальних капітальних інвестицій у Волинській та Рівненській областях за 2010-2019 рр. (побудовано авторами за даними [9-11]) 
Порівняння реальних показників капітальних інвестицій в порівняних цінах 2010 року свідчить про дещо іншу ситуацію, адже їх тенденції вже не характеризуються постійним щорічним зростанням, а навпаки - циклічними змінами, що пов'язуються із відповідними змінами економічної активності в країні. Зокрема, можна відмітити період 2010-2013 pр., коли було забезпечено позитивне зростання суми капітальних інвестицій у вказаних регіонах, яке не було таким значним, як по номінальних показниках.

Але надалі, у зв'язку з негативними наслідками економічної кризи, викликаної позачерговою зміною влади, анексією частини території нашої країни та проведенням ATO, у 2014 році відбулося зниження капітальних інвестицій у Волинській області на 255,9 млн грн, або 9,1\%, а у Рівненській області - на дещо більші 283,1 мн грн, або 11,8\%. Надалі після певного зростання у 2015 році, знову відбулося зниження капітальних інвестицій по обидвох регіонах у 2016 році. При цьому, по Волинській області спад продовжився і у 2017 році, але надалі у 2019 році було досягнуто максимальне значення цього показника за увесь аналізований період - 4112 млн грн. Тоді як у Рівненській області навпаки у 2019 році було допущено зниження реальних капітальних інвестицій до 2185 млн грн, тобто до рівня практично співставного з 2014 роком.

Тобто можна констатувати, що за реальними оцінками обсяг капітального інвестування залежить від економічної ситуації в країні та є нестабільним, але, виходячи з вивчених тенденцій, більш активно здійснюється інвестиційна діяльність у Волинській області, тоді як у Рівненській області, навпаки допущено зниження суми капітальних інвестицій, що негативно вплине на їі економічний розвиток в майбутньому.

Надалі важливо також провести порівняння тенденцій зміни номінальної та реальної суми капітальних інвестицій загалом Північно-Західного регіону України за 2010-2019 рр. (рис. 2).

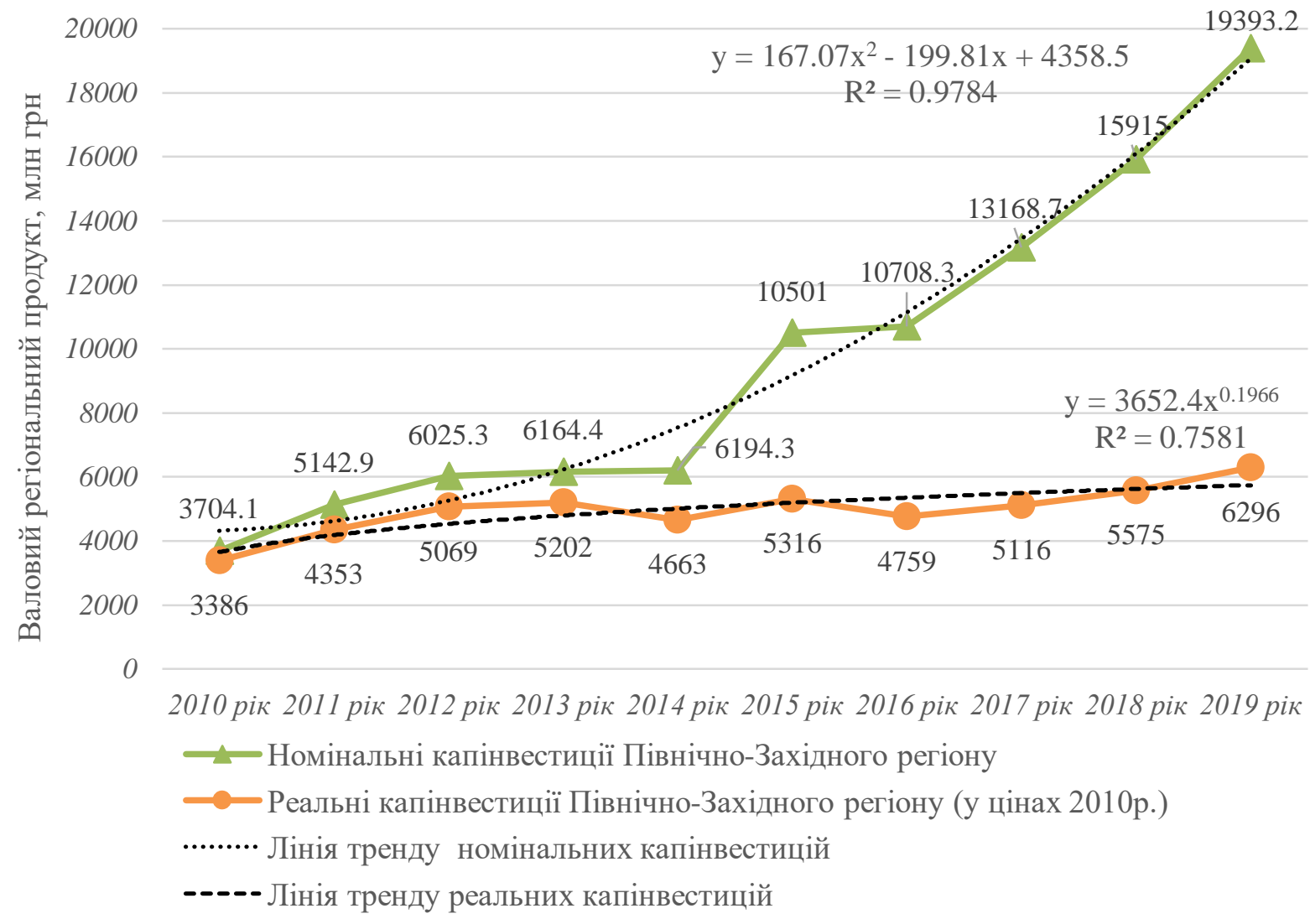

Рис. 2. Порівняння тенденцій номінальної та реальної суми капітальних інвестицій Північно-Західного регіону України за 2010-2019 рр. (побудовано авторами за даними [9-11]) 
Загалом протягом тривалого періоду спостерігалося постійне зростання номінальної суми капітальних інвестицій - з 3704,1 млн грн у 2010 році до 19393,2 млн грн у 2019 році, або у 5,2 рази. При цьому, найбільший приріст спостерігався після 2014 року, коли у 2015 році цей показник збільшився у 1,7 рази до попереднього року, що значною мірою пов'язується не з покращенням інвестиційного клімату, а з наростанням фінансової нестабільності в країні, що супроводжувалося різким зростанням інфляції.

Підтвердженням цього стало вивчення тенденцій реальної суми капітальних інвестицій у цінах 2010 року, яка до кризового 2014 року мала тенденцію до зростання з 3386 млн грн у 2010 році до 5202 млн грн у 2013 році, або у 1,5 рази, але знизилася до 4663 млн грн, або на 10,4\%, у 2014 році. Надалі після певного зростання у 2015 році, цей показник знову знизився у 2016 році, але в напутніх роках тенденція залишалася позитивною, що в підсумку дозволило у 2019 році досягнути максимального значення за увесь звітний період - 6296 млн грн, що на 35,0\% більше кризового 2014 року.

Тобто, за реалістичними оцінками сума капітальних інвестицій не мала такого позитивного приросту, як за номінальними показниками без урахування інфляції. Загалом тільки 2018-2019 рр. було забезпечено перевищення реальної суми капітальних інвестицій, якої було досягнуто у докризовому 2013 році, та досягнуто максимуму за увесь період оцінювання.

Також вадливе значення має проведення порівняння динаміки капітальних інвестицій у Північно-Західному регіоні України протягом 2010-2019 рр. за основними видами активів - у матеріальні чи нематеріальні активи (рис. 3).

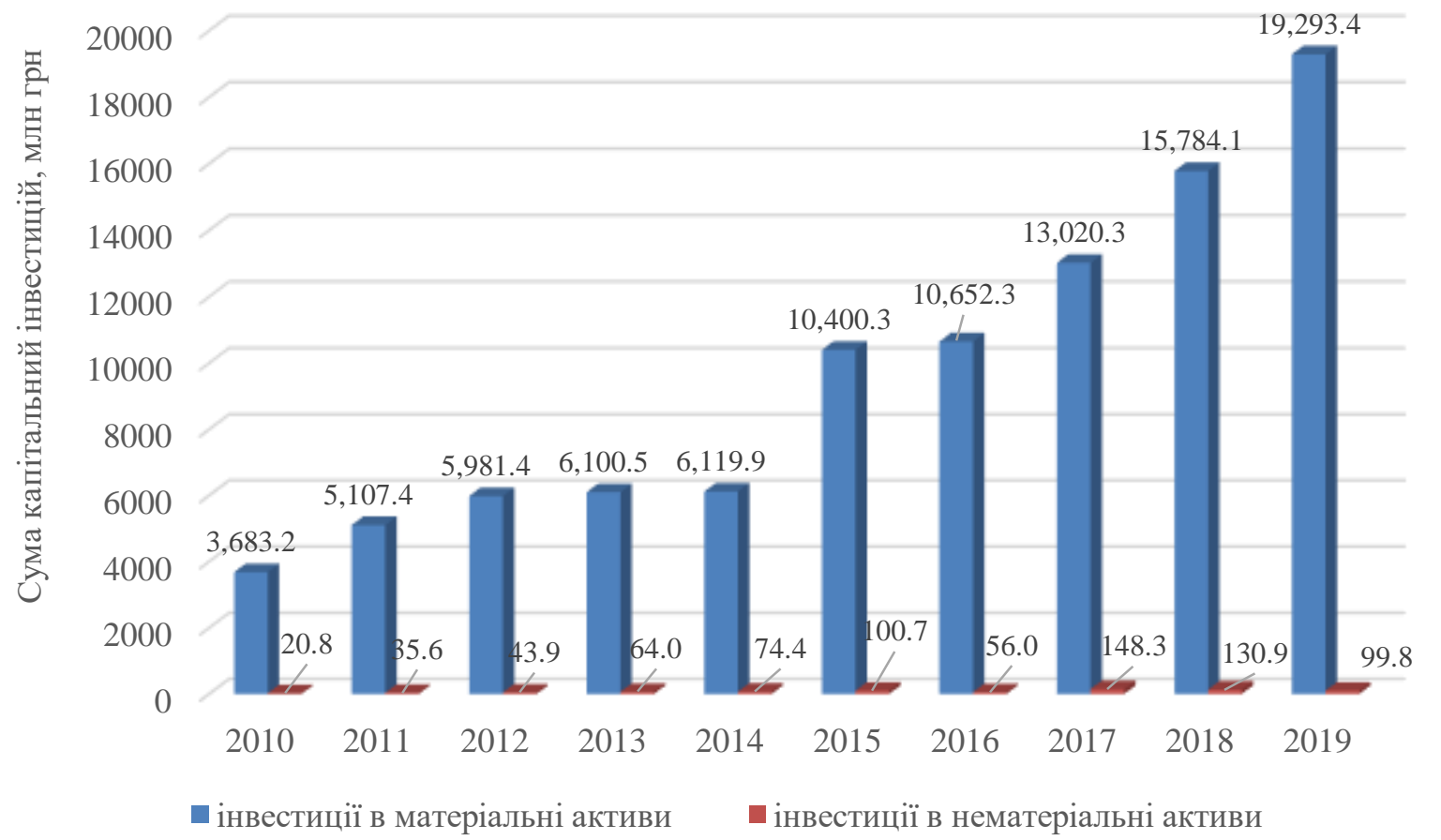

Рис. 3. Порівняння динаміки капітальних інвестицій у матеріальні та нематеріальні активи у Північно-Західному регіоні України за 2010-2019 рр. . (побудовано авторами за даними [9-11])

Як бачимо, основна сума капітальних інвестицій протягом усього аналізованого періоду припадала на інвестиції у матеріальні активи, яка збільшилася з 3683,2 млн грн у 2010 році до 19293,4 млн грн у 2019 році, або у 5,2 рази. Тоді як сума капітальних інвестицій у нематеріальні активи хоча й збільшувалася аналогічними темпами відповідно з 20,8 млн грн до 99,8 млн грн, або у 5 разів, але була значно меншою. Адже 
питома вага інвестицій в нематеріальні активи протягом усього аналізованого періоду коливалася у межах $0,5-1,2 \%$. Тобто суб'єкти господарювання у регіоні мало уваги приділяють здійсненню капітальних інвестицій у нематеріальні активи (зокрема у комерційні права, програмне забезпечення, бази даних тощо), що свідчить про певну відсталість від світових тенденцій глобалізації та інформатизації економіки. При цьому, навіть у 2018-2019 роках навіть відбулося зменшення цих інвестицій порівняно 3 максимальним рівнем, досягнутим у 2017 році - 148,3 млн грн.

Поряд 3 вивченням тенденцій за видами інвестування виникає необхідність детальнішого аналізу зміни структури капітальних інвестицій за джерелами фінансування у Північно-Західному регіоні України за 2010-2019 рр. (рис. 4).

Як бачимо, протягом аналізованого періоду основним джерелом фінансування капітальних інвестицій були власні кошти підприємств і організацій, питома вага їх коливалася від мінімальних 43,6\% у 2010 році до максимальних 63,5\% у 2015 році, але надалі у 2019 року вона знову знизилася до 45,1\%. Тобто у періоди економічної нестабільності прогнозовано підприємства і організації збільшували частку капітальних інвестицій з власних джерел. Частка фінансування капітальних інвестицій з держаного бюджету була чи не найменшою, коливаючись у межах 0,8-5,6\%.

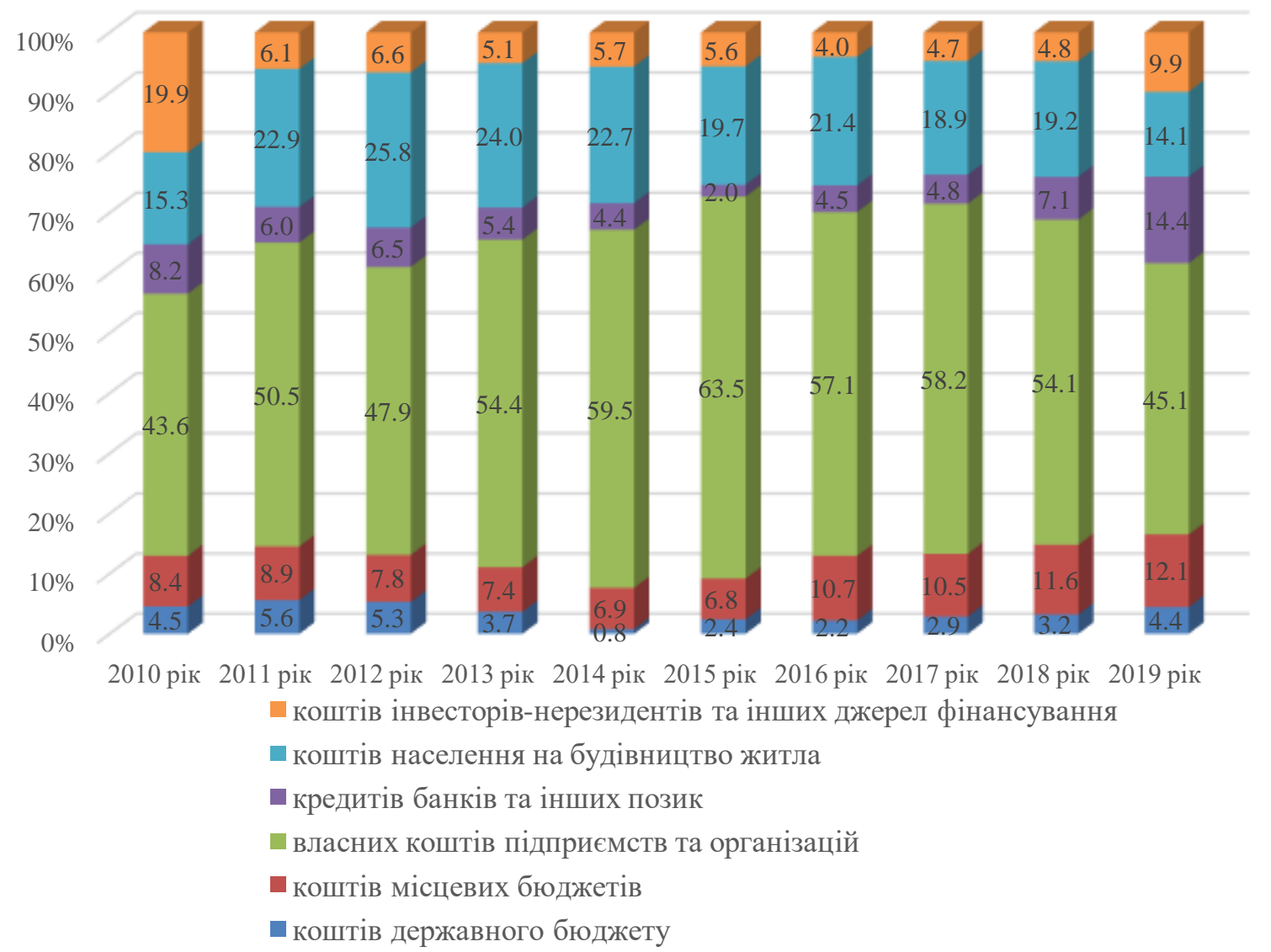

Рис. 4. Зміна структури капітальних інвестицій за джерелами фінансування у Північно-Західному регіоні за 2010-2019 рр. . (побудовано авторами за даними [9-11])

Дещо більшою, але також незначною була частка капітальних інвестицій 3 місцевого бюджету - коливалася у межах 6,9-12,1\%. Загалом бюджетні кошти витрачалися переважно на капітальне інвестування у невиробничій сфері медицина, освіта, культура, соціальне обслуговування тощо), а обсяг фінансування передано залежав від економічної ситуації в країні та регіоні. Адже в період економічної кризи 2014 року питома вага фінансування 3 місцевого та державного бюджетів була 
мінімальною - відповідно 6,9\% та $0,8 \%$. Подібна ситуація була характерною і щодо зміни частки фінансування за рахунок кредитів і позик, яка отримала мінімальне значення у 2015 році - 2,0\%, а максимальне у 2019 році - 14,4\%, а також за рахунок коштів інвесторів-нерезидентів та інших джерел фінансування - мінімум частки 4,0\% досягнуто у 2015 році, а максимум - 19,9\% у 2010 році. Зміна частки фінансування коштів населення на будівництво житла значною мірою залежало як від економічної ситуації, так і від пріоритетів держави та зацікавленості бізнесу щодо реалізації відповідних програм будівництва на пільгових умовах, адже найбільшою вона була у докризовому 2012 році - 25,8\%, а найменшою - 14,1\% у 2019 році.

Надалі вивчено динаміку суми капітальних інвестицій за основними видами економічної діяльності у Північно-Західному регіоні України за 2010-2019 рр. (рис. 5).

Як бачимо, після 2015 року найбільшою сумою капітальних інвестицій характеризувалася сфера промисловості, яка досягнула максимуму у 2019 році 8142 млн грн. Також значним обсягом інвестицій протягом усього періоду відзначалася сфери будівництва та сільського, лісового та рибного господарства, хоча їх розмір дещо знизився у 2019 році. Після 2014 року постійним зростанням інвестування відзначалася й сфера державного управління й оборони, обов'язкового соціального страхування.

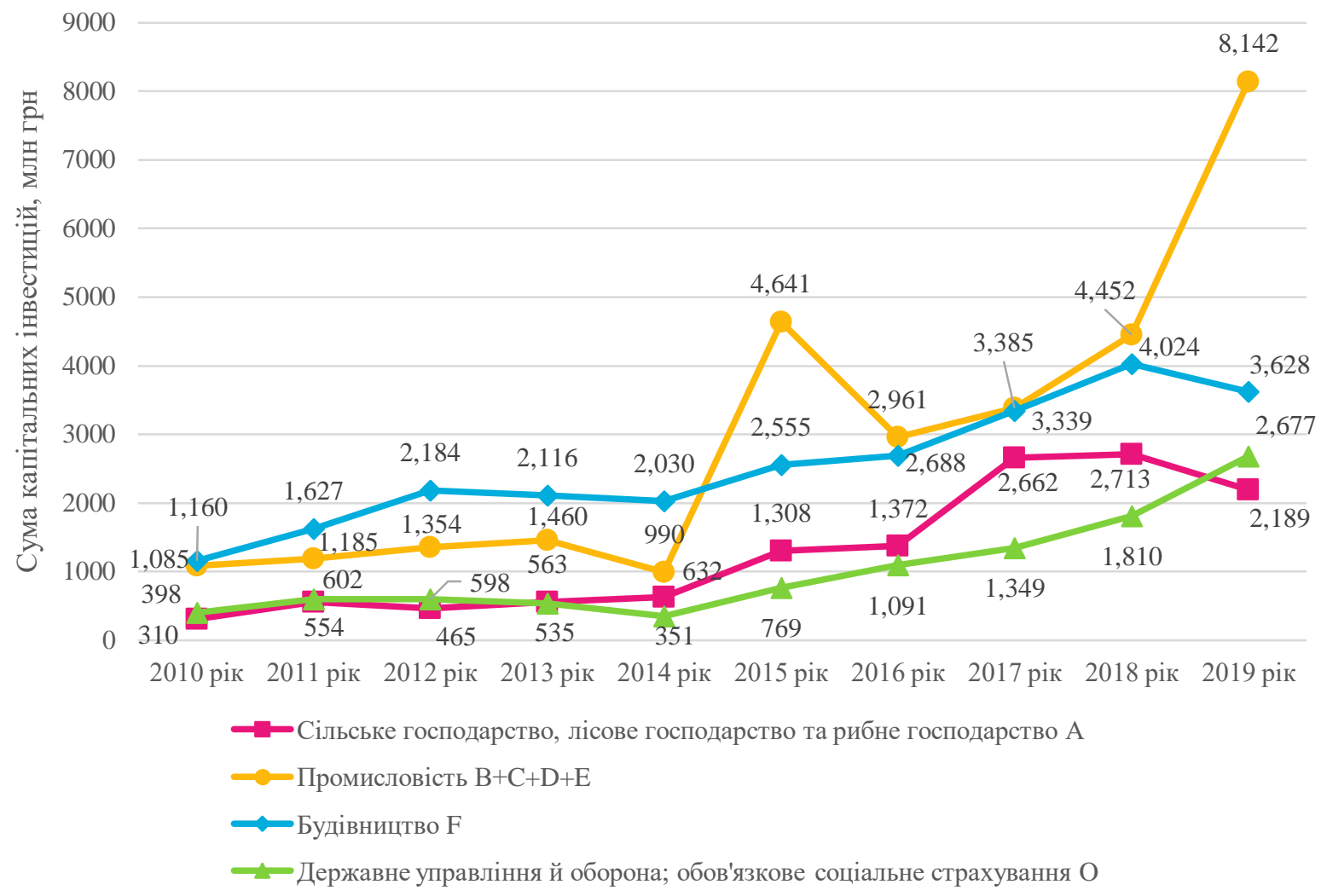

Рис. 5. Динаміка суми капітальних інвестицій за основними видами діяльності у Північно-Західному регіоні України за 2010-2019 рр. (побудовано за даними [9-11])

Детальніший аналіз динаміки капітальних інвестицій в охорону навколишнього природного середовища у Північно-Західному регіоні України за 2010-2019 рр. (рис. 6) показав, що основними напрямками інвестування стали очищення зворотних вод та поводження з відходами, на які у 2019 припадало, відповідно 64,9\% та 28,4\% коштів. 


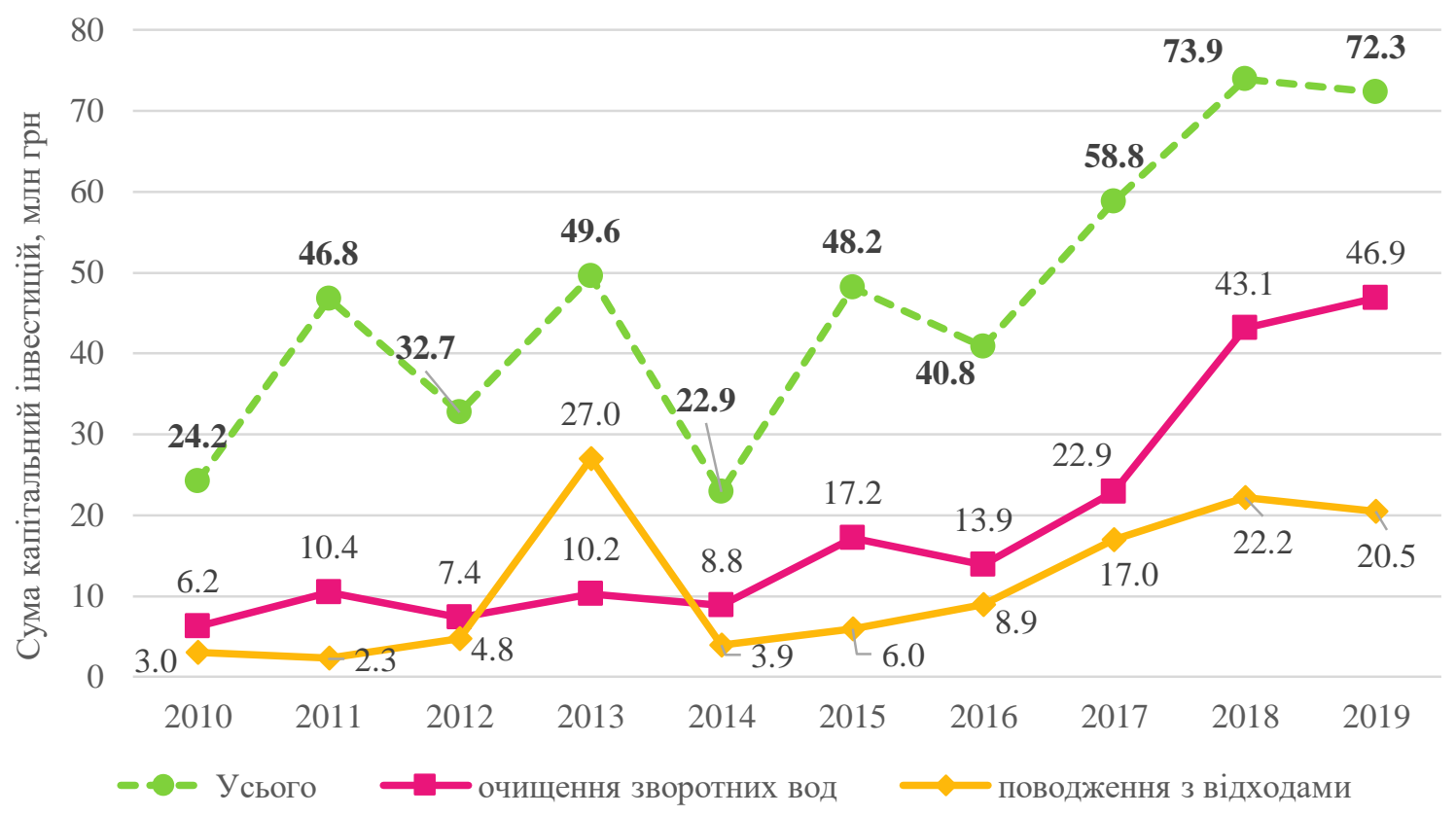

Рис. 6. Динаміка капітальних інвестицій в охорону навколишнього природного середовища у Північно-Західному регіоні за 2010-2019 рр. (побудовано авторами за даними [9-11])

При цьому, загальна сума капітальний інвестицій збільшувалася - 324,2 млн грн у 2010 році до 72,3 млн грн у 2019 році, або у 3 рази, але спостерігалося ії зменшення у 2012, 2014 та 2016 роках. Але загалом сума капітальних інвестицій в охорону навколишнього природного середовища була незначною і у 2019 році становила лише 0,4\% від загальної їх суми, тоді як у 2010 році цей показник був дещо більшим - 0,7\%. Все це говорить про недостатність капітального інвестування природоохоронної діяльності у Північно-Західному регіоні, який є достатньо перспективним з позицій використання потужного природно-ресурсного потенціалу для економічного зростання.

Висновки. Для макро регіонів України, до яких віднесено Північно-Західний регіон, до складу якого входять Волинська та Рівненська області, важливе значення має формування ефективної системи фінансового забезпечення їх інвестиційної діяльності.

Вивчення тенденцій зміни ряду основних показників, які характеризують фінансове забезпечення інвестиційної діяльності на регіональному рівні за тривалий період 2010-2019 рр. дозволило виявити ряд проблемних моментів: номінальні суми капітальних інвестицій постійно зростають, але за реальними оцінками вони зменшуються у періоди економічної нестабільності; Волинська область переважає Рівненську за сумою та позитивною динамікою капітальних інвестицій; за номінальними оцінками сума капітальних інвестицій за звітний період зросла у 5 разів, а за реальними за виключенням впливу інфляції - менше, ніж у 2 рази, а за прогнозами надалі продовжиться помірне ії зростання; основна сума капітальних інвестицій припадає на матеріальні активи, тоді як невиправдано низьким є інвестування в нематеріальні активи; переважним джерелом фінансування залишаються власні кошти підприємств; серед видів діяльності найбільше інвестицій здійснюється у промисловість та будівництво; недостатнім $є$ рівень інвестування в охорону навколишнього природного середовища.

Тому в наступних періодах особливе значення для Північно-Західного регіону має створення сприятливих умов для збільшення капітальних інвестицій як в матеріальні, так i нематеріальні активи, адже вони забезпечать оновлення основного капіталу на інноваційній основі, що дозволить збільшити виробництво конкурентоспроможної на 
внутрішньому та зовнішньому ринках збуту продукції на основі залучення потужного природно-ресурсного потенціалу даного марко регіону, що в кінцевому підсумку сприятиме підвищення рівня його соціально-економічного розвитку.

\section{Список бібліографічного опису}

1. Соціально-економічний потениіал сталого розвитку України та ї регіонів: вектори реального поступу : національна доповідь / за ред. акад. НАН України Е.М. Лібановоі, акад. НААН України М.А. Хвесика. К. : ДУ ІЕПСР НАН України, 2017. $864 \mathrm{c}$.

2. Державні фінанси Украӥни: розвиток та управління змінами (проблеми економічної безпеки) / за ред. Т.І. Єфименко; ДННУ «Акад. фін. Управління». Київ, 2017. 496 с.

3. Голян В. А., Заставний Ю. Б. Фінансово-економічна підтримка сільського господарства: специфіка органічних виробництв. Агросвіт. 2020. № 4. С. 27-34.

4. Васьківська К. В., Васьківський Ю. П., Децик О. І., Прокопишак В. Б. Фінансове забезпечення інвестиційної діяльності суб'єктів підприємництва: регіональний аспект. Ефективна економіка. 2018. № 7. URL: http://www.economy.nayka.com.ua/?op=1\&z=6444

5. Васьківська К. В., Децик О. І., Прокопишак О. Б. Фінансове забезпечення інвестиційної діяльності суб’єктів підприємництва: теоретичний аспект. Socio-economic problems of the modern period of Ukraine. 2017. Випуск 3 (125). C. 47-51.

6. Марусяк Н. Л. Фінансове забезпечення інвестиційної діяльності підприємств прикордонної території західного регіону в умовах євроінтеграції. Науковий вісник Чернівецького національного університету: Вип. 773-774. Економіка. Чернівці: Чернівецький нац. ун-т, 2016. С. 146-149.

7. Петренко Л. М. Основні елементи фінансового забезпечення інвестиційного розвитку регіону. Приазовський економічний вісник. 2018. 1 (6). С. 142-147.

8. Шубалий О. М., Косінський П. М. Економічне стимулювання комплексної переробки природних ресурсів у регіоні : монографія. Луцьк : IBВ Луцького НТУ, 2019. 218 с.

9. Головне управління статистики у Волинській області : офіційний веб-сайт: URL: http://www.lutsk.ukrstat.gov.ua.

10. Головне управління статистики у Рівненській області : офіційний веб-сайт: URL: http://www.gusrv.gov.ua.

11. Державна служба статистики Украӥни : офіційний веб-сайт: URL: http://www.ukrstat.gov.ua.

\section{References}

1. Libanova E.M., Khvesyk M.A. et al. (2017). Sotsial'no-ekonomichnyy potentsial staloho rozvytku Ukrayiny ta yiyi rehioniv: vektory real'noho postupu : natsional'na dopovid' [Socio-economic potential of sustainable development of Ukraine and its regions: vectors of real progress: national report]. Public Institution «Institute of Environmental Economics and Sustainable Development of the National Academy of Sciences of Ukraine». Kyiv. 867 p. [in Ukrainian].

2. Yefimenko T.I. et al. (2017). Public Finance of Ukraine: Development and Change Management (Economic Security Issues) [Public Finance of Ukraine: Development and Change Management (Economic Security Problems)]. State educational and scientific establishment "The Academy of Financial Management". Kyiv. 496 p. [in Ukrainian].

3. Golyan, V. and Zastavnyy, Y. (2020). Finansovo-ekonomichna pidtrymka sil's'koho hospodarstva: spetsyfika orhanichnykh vyrobnytstv [Financial and economic support for agriculture: specifics of organic production], Ahrosvit-Agrosvit. Vol. 4, 2734. [in Ukrainian].

4. Vaskivska, K., Vaskivskyy, Y., Decyck, O. and Prokopyshak, V. (2018). Finansove zabezpechennya investytsiynoyi diyal'nosti sub"yektiv pidpryyemnytstva: rehional'nyy aspekt [Financial support of investment activity of business entities: regional aspect]. Efektyvna ekonomika - Efficient economy, [Online], vol. 7, Retrieved from: http://www.economy.nayka.com.ua/?op=1\&z=6444 [in Ukrainian].

5. Vaskivska K., Decyk O., Prokopyshak O. (2017). Finansove zabezpechennya investytsiynoyi diyal'nosti sub"yektiv pidpryyemnytstva: teoretychnyy aspekt [Financial provider of investment activities of business enterprises: theoretical aspects]. Socio-economic problems of the modern period of Ukraine. Vol. 3(125), 47-51. [in Ukrainian].

6. Marusyak N.L. (2016). Finansove zabezpechennya investytsiynoyi diyal'nosti pidpryyemstv prykordonnoyi terytoriyi zakhidnoho rehionu $\mathrm{v}$ umovakh yevrointehratsiyi [Financial support of investment activity of the enterprises of the frontier territory of the western region in the conditions of European integration]. Naukovyy visnyk Chernivets'koho natsional'noho universytetu: Ekonomika - Scientific Bulletin of Chernivtsi National University: Vol. 773-774. Economy. Vol. 773-774, 146149. [in Ukrainian].

7. Petrenko L.M. (2018). Osnovni elementy finansovoho zabezpechennya investytsiynoho rozvytku rehionu [The main elements of financial support of investment development of the region]. Pryazovs'kyy ekonomichnyy visnyk - Priazovsky Economic Bulletin. Vol. 1(6), 142-147. [in Ukrainian].

8. Shubalyi O. M., Kosinskyi P. M. (2019). Ekonomichne stymulyuvannya kompleksnoyi pererobky pryrodnykh resursiv u rehioni [Economic stimulation of complex processing of natural resources in the region]. Lutsk. 218 p. [in Ukrainian].

9. Holovne upravlinnya statystyky u Volyns'kiy oblasti: ofitsiynyy veb-sayt [Main Department of Statistics in the Volyn region. Official website]. Retrieved from: http://www.lutsk.ukrstat.gov.ua [in Ukrainian].

10. Holovne upravlinnya statystyky u Rivnens'kiy oblasti: ofitsiynyy veb-sayt [Main Department of Statistics in Rivne Region: official website]. Retrieved from: http://www.gusrv.gov.ua [in Ukrainian].

11. Derzhavna sluzhba statystyky Ukrayiny: ofitsiynyy veb-sayt [State Statistics Service of Ukraine: official website]. Retrieved from: http://www.ukrstat.gov.ua [in Ukrainian].

Дата подання публікації 20.12.2020 р. 